\title{
Exclusive Brand Outlet Expansion Framework for Lifestyle Brands in India (EBOE-LS)
}

\author{
H. R. Ganesha ${ }^{1}$, \& P. S. Aithal ${ }^{2}$ \\ ${ }^{1}$ Chief Executive Officer - Consulting Division, Gramss Retail Trading Private Limited, \\ Bengaluru - 560078, India and Post-Doctoral Research Fellow, College of Management \& \\ Commerce, Srinivas University, Mangalore - 575001, India. \\ OrcidID: 0000-0002-5878-8844; E-mail: hrganesha@yahoo.co.in \\ ${ }^{2}$ Vice Chancellor, Srinivas University, Mangalore - 575001, India. \\ OrcidID: 0000-0002-4691-8736; E-mail: psaithal@gmail.com
}

Area of the Paper: Business Management.

Type of the Paper: Research Paper.

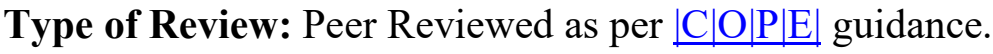

Indexed In: OpenAIRE.

DOI: http://doi.org/10.5281/zenodo.3976932.

Google Scholar Citation: IJCSBE.

\section{How to Cite this Paper:}

Ganesha, H. R., Aithal, P. S. (2020). Exclusive Brand Outlet Expansion Framework for Lifestyle Brands in India (EBOE-LS). International Journal of Case Studies in Business, IT, and Education (IJCSBE), 4(2), 1-17. DOI: http://doi.org/10.5281/zenodo.3976932.

International Journal of Case Studies in Business, IT and Education (IJCSBE)

A Refereed International Journal of Srinivas University, India.

(C) With Authors.

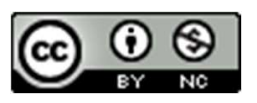

This work is licensed under a Creative Commons Attribution Non-Commercial 4.0 International License subject to proper citation to the publication source of the work.

Disclaimer: The scholarly papers as reviewed and published by the Srinivas Publications (S.P.), India are the views and opinions of their respective authors and are not the views or opinions of the S.P. The S.P. disclaims of any harm or loss caused due to the published content to any party. 


\title{
Exclusive Brand Outlet Expansion Framework for Lifestyle Brands in India (EBOE-LS)
}

\author{
H. R. Ganesha ${ }^{1}$, \& P. S. Aithal ${ }^{2}$ \\ ${ }^{1}$ Chief Executive Officer - Consulting Division, Gramss Retail Trading Private Limited, \\ Bengaluru - 560078, India and Post-Doctoral Research Fellow, College of Management \& \\ Commerce, Srinivas University, Mangalore - 575001, India. \\ OrcidID: 0000-0002-5878-8844; E-mail: hrganesha@yahoo.co.in \\ ${ }^{2}$ Vice Chancellor, Srinivas University, Mangalore - 575001, India. \\ OrcidID: 0000-0002-4691-8736; E-mail: psaithal@gmail.com
}

\begin{abstract}
Though EBOs' (Exclusive Brand Outlet) risk-mitigation is a collective responsibility of lifestyle brand and the expansion partner (franchisee), a majority of lifestyle brands in India believe that the risk of capital investment/recurring expenses of EBOs and profit generated by EBOs has to be owned by the expansion partner. This belief and unbalanced business strategy of lifestyle brands though attract franchisees in the early stages of EBO expansion due to the brand's reputation in the market or initial lucrative contract terms, it seriously fails to bring any long-term strategic and competitive advantages to the lifestyle brand as the drop-out rate of expansion partners increase significantly after one year of operation. This belief is also distracting lifestyle brands from understanding the long-term positive impact of EBO expansion frameworks that could balance the risk-mitigation and profits between the brand and the expansion partner. A single theory, model and framework of 'Firm-Contracts' and 'Distribution Systems' from the existing literature available across perspectives, paradigms, and areas of study (Economics, Business Law, Market Penetration, Business Strategy, Marketing and so on) is not entirely applicable that could be adopted to suit lifestyle brand's EBO expansion plan in India and designing a framework without empirical pieces of evidence is also not appropriate. In this study, (i) we have studied existing theories, models and frameworks relevant to market penetration and expansion; (ii) analyzed 24 months' of actual EBO data of a few select organized lifestyle brands in India across their existing expansion models; (iii) borrowed experimental findings and insights from previous studies relevant in this context, to identify key decision and investment-making areas that could result in a balanced business contract between a lifestyle brand and the expansion partner thereby designing an economical/effective framework that would be useful in deployment of appropriate tactics of deciding a right EBO type for every City Type and the Store Location by a lifestyle brand in India. The framework is named as EBOE-LS.
\end{abstract}

Keywords: Indian Retail, Lifestyle Consumer, Lifestyle Brand, Exclusive Brand Outlet, EBO, Franchising, Retail Expansion, Distribution Systems, Firm Contracts, Balanced Business Partnership, Market Penetration, Franchising Theory, EBOE-LS.

\section{INTRODUCTION :}

Lifestyle Brand: Each individual wants to have a unique identity that could be based on his/her, a) background such as nationality, ethnicity, culture, subculture, social class, affiliation, environment, etc; b) experiences and c) choices. Lifestyle brands attempt to evoke emotional connections between consumers and they need to have a unique identity and most importantly lifestyle brands are increasingly becoming one of the key components of consumer's self-expression [1]. To ensure the scope of this study is focussed, we define lifestyle brands as the ones, who attempt to offer a complete solution for a specific or wider lifestyle needs of consumers through their products such as Apparel, 


\section{International Journal of Case Studies in Business, IT, and Education SRINIVAS (IJCSBE), ISSN: 2581-6942, Vol. 4, No. 2, August 2020.

Footwear, Accessories, and Lifestyle Essentials with an ultimate goal of their products being key contributors of an implicit or explicit statement of consumers personality and identity. Lifestyle retail market size in India is expected to reach 130 billion USD by the year 2023 which is a 77 percent growth when compared to the year 2013 [2]. Based on India's 2011 census, the United Nation's (UN) Department of Statistics and Program Implementation estimates the Indian population to reach close to 1.38 billion by the year 2020 [3]. It is estimated that more than 300 Global lifestyle brands have plans to open their stores in India this year [4].Organized retailing in India is expected to have approximately 25 percent of the market share by the year 2021 which was at 12 percent in the year 2017 [5].India has attracted many global lifestyle brands. Few Global brands have attempted to offer their product assortment as being an SIS at select large MBO stores, few have offered their product assortment through EBOs, few have shown their presence only in online stores and few have licensed their brands to third parties or entered into a Joint Venture to offer their products in Indian retail market. To name a few Levi's, Zara, United Colors of Benetton, Marks \& Spenser, H\&M, Mother Care, Carter's, Puma, Nike, Adidas, Reebok, Armani Exchange, Diesel, Gas, Gap, The Children's Place, Quiksilver, Superdry, Kappa, Bossini, Calvin Klein, Hanes, Tommy Hilfiger, Ed Hardy, Izod, Nautica, Arrow, U.S. Polo Assn, Jack \& Jones, Vero Moda, Tumi, Lee, Hero, Maverick, Wrangler, Fila, and Jockey. India is also a home for a vast number of lifestyle brands that originated from India. One can list more than 5000 lifestyle brands in India [6] of which few of them have a strong presence all over India, few have strong presence only in certain regions of India and few are available only online. It is evident that, despite such humongous number of lifestyle brands available in India one could list only a few which can be tagged as well-known/familiar/reputed Indian lifestyle brands such as, Biba, Manyavar, Soch, Gini \& Jony, Blackberrys, Louis Phillipe, Peter England, Provogue, Monte Carlo, Mufti, W for Women, Oxemberg, Indian Terrain, Global Desi, Parx, S Kumar's, Vimal, Mini Klub, Aurelia, Sparx, Campus, Go Colors, Enamour, HiDesign, Lino Perros, Idee, Spykar, Killer Jeans, Flying Machine, Da Milano, Park Avenue, Ethnix, ColorPlus, Lux Cozy, WildCraft, 612 League, WLS, John Players, Fastrack, 109 F, Proline, Image, Jealous 21, Liberty, Paragon and few more. Only a few names from the list of more than 5000 brands possibly indicating that despite humongous population and the retail market size in India, majority of Indian lifestyle brands have failed to establish themselves as true lifestyle brands and we would attribute the majority of this failure to their existing distribution channel strategy in addition to their existing Marketing Mix. Dominantly a majority of lifestyle retailers in India offer just one of the groups such as a) product-specific; b) gender-specific; c) need-specific; d) fashion-specific; e) function-specific; f) category-specific; g) life stage-specific; h) occasion-specific, and very few cater to multiple products offering to multiple consumer groups [7].

Location and City Tier: In India, the real estate sector has grown exponentially in recent years. The sector could be thirteen percent of Indian GDP by the year 2025, and by the year 2030, the sector is expected to reach one trillion USD mark which was at 120 billion USD in the year 2017 [8]. India is one of the most sought-after countries for retailing opportunities globally, mainly because of i) higher population consisting of the relatively younger population and ii) higher penetration of internet users. India is witnessing rapid expansion of national and international brands/companies into Tier-2 and Tier-3 cities such as Housing, Automobiles, IT, Banking and most importantly Retail Stores owing to; i) exponential growth in the urbanization of Tier-2 and Tier-3 cities post-economic liberation, ii) government's interest and plans for improving basic infrastructure at Tier-2 and Tier-3 cities, vi) relatively cheaper real estate, and most importantly vi) steadily increasing disposable income level of consumers in Tier-2 and Tier-3 cities. As per McKinsey Global Institute study by the year 2030, urban agglomerations in India could lead to increase in the middle-class consumer segment by 3 times compared to the year 2010 which was at 22 million; people living in urban cities is expected to increase to 590 million and most important cities with more than one million population will increase to 68 [9]. It is observed that lifestyle brands of national image determine the city chosen for the retail expansion based on market reports available on the general population of consumer and due to this what is happening is that most of the price/product assortment of lifestyle brands are differentiated in Tier-2 and Tier-3 cities compared to Tier-1 cities which potentially creates negative perceptions about a brand in consumers' minds [10]. 


\section{International Journal of Case Studies in Business, IT, and Education SRINIVAS (IJCSBE), ISSN: 2581-6942, Vol. 4, No. 2, August 2020. \\ PUBLICATION}

Expansion Channels: Indian retail market, despite being significantly skewed towards unorganized retailing, has also witnessed many organized retailers and distribution channels relevant for a lifestyle brand's retailing expansion such as; i) $M B O$ Local Retailers that are Multi-Branded brick-and-mortar stores managed by retailers having their presence only in a particular city of India and allow lifestyle brands to showcase and sell their products through a shop-in-shop method (for example, Channabasappa \& Sons Davanagere, Karnataka); ii) MBO Regional Retailers are Multi-Branded brickand-mortar stores managed by retailers having their strong presence in specific regions of India and allow lifestyle brands to showcase and sell their products through a shop-in-shop method (for example, Kapsons Punjab); iii) MBO National Retailers are Multi-Branded brick-and-mortar stores managed by retailers having their presence all over India and allow lifestyle brands to showcase and sell their products through a shop-in-shop method (for example, Shoppers Stop); iv) EBO Offline that are brickand-mortar stores selling products belonging to the brand exclusively commonly known as Exclusive Brand Outlets; v) EBO Online: Online store selling products belonging to the brand exclusively; vi) $M B O$ Speciality Online Retailers are Multi-Branded online stores managed by retailers and focussed on specific categories of products and allow lifestyle brands to list and sell their products (for example, Myntra); vii) $M B O$ Generalist Online Retailers that are Multi-Branded online stores managed by retailers and mostly sell all the categories of products and allow lifestyle brands to list and sell their products (for example, Flipkart). Dominantly majority of lifestyle brands in India have shown presence in just one or a few of these channels and very few have shown their presence in multiple distribution channels across the country. Inevitably, in addition to having a rational distribution channel mix, it becomes imperative for any lifestyle brand in India to have a framework that would guide them in retailing expansion through EBOs as the same requires long-term capital commitment from the brand [11].

\section{LITERATURE REVIEW :}

EBOs in India: The location of an EBO determines most of the store operating costs, be it fixed or variable viz., rent, common area maintenance (CAM) costs, number of sales personnel, house-keeping charges, maintenance costs, security-related costs, etc. The rental component of this cost structure contributes to the largest part of the fixed cost structure of an EBO and the same varies by EBO location; be it high street, mall, or institutional along with a steady increase year-on-year on pre-agreed terms. Rent is one of the most important costs in retailing which holds a significant share of overall retailing cost structure and most importantly due to its fixed cost nature it becomes even more important aspect of retailing which has a direct impact on overall retailing profitability. One could argue that a lifestyle brand must open EBOs in locations that attract a larger number of consumers who are willing to spend more, but unfortunately, it is not that simple, EBO location choice for lifestyle brands is truly a complex task and a majority of the time more attractive the location more expensive it is for the brand. Every lifestyle brand needs to have its EBOs presence in different locations to have a strategic and competitive advantage as far as the brand image in consumers and competitor's minds is concerned and hence it is inevitable for them to open a few EBOs in premium locations too. The consumer store choice angle to the EBO location is the one that puts many lifestyle brands in a quandary while considering the EBO location for their specific retailing formats. By its nature, this decision is capital intensive and requires brands to commit long-term lock-ins with the property/realty owners/partners. Every lifestyle brand thus, expects the EBOs location to attract many relevant consumers, generate higher revenue and profits failing which could lead them to spend additional money to attract and acquire new consumers to EBOs. The EBO location becomes even more important for lifestyle brands offering multiple categories in their stores, catering to multiple life-stage needs of a consumer and comprises of many products/categories which are designed to serve specific needs of consumers. EBO location is also one of the most important determinants for brands as far as retail expansion is concerned. The popular location choices available for an EBO in India are a) central market area also known as highstreets; b) residential market areas also known as neighborhoods; c) large commercial complexes and malls; d) designated shopping area in larger campuses, tech parks, resorts, hospitals, and apartments also known as institutional. It is inevitable for national-level lifestyle brands to have EBOs present in as many different locations as possible to have a competitive advantage over competitors and unorganized local favorites. But, all the stores, all the locations, and all the cities in a 


\section{International Journal of Case Studies in Business, IT, and Education SRINIVAS (IJCSBE), ISSN: 2581-6942, Vol. 4, No. 2, August 2020.

particular country behave differently in terms of revenue and profits they generate for the brand. Few established lifestyle brands have also taken advantage of their brand image and brand equity to attract franchisee partners to operate EBOs that are known to be one of the best ways to expand brand presence through EBOs without huge capital investments from the brand. Amongst all the distribution channels available in India EBO is the only channel that enables lifestyle brands to understand, interact, and maintain a long-term relationship with their consumers better than any other distribution channels. EBO also help lifestyle brands to communicate real-time offerings of the brand across products and promotions in addition to having higher possibilities of showing the real brand experience to consumers. Notwithstanding huge capital investment and commitment for the lifestyle brand, EBOs probably add more value to the brand on overall brand image in employees, investors, competitors, and consumer's minds as the majority of the variables directly impact overall brand profitability at store level are controlled by the lifestyle brand itself. The rational distribution channel mix if executed efficiently can also possibly attract many new investors in the form of Franchisees who can help the brand is expanding its presence across the country through EBO stores at very minimal or no capital investment and commitment involved [11-12].

EBO Expansion Partners: Globally, franchising has been one of the capital-friendly and marketfriendly models of expanding a brand's EBO presence across geography. It is easier for an established brand to attract a franchise but at the same time, it is difficult for a young brand to attract a franchisee and if available venture capital is an optional source of capital but the same is not cheaper compared to a franchise capital [13]. The International Franchise Association (IFA) defines a full business format franchise as 'a contractual relationship between the franchisor (brand) and the franchisee (expansion partner) in which the franchisor offers or is obliged to maintain a continuing interest in the business of the franchisee in such areas as know-how and training, wherein the franchisee operates under a common trademark, format or procedure owned or controlled by the franchisor, under which the franchisee has or will make a substantial capital investment in his business from his resources'. Franchisee coordination and monitoring is a substantial cost of franchising model and the same can be reduced if the franchisor also has EBOs operated by them in the same region wherein the franchisor also has few EBOs operated by franchisees [14]. Literature in franchising has tested and accepted two key theories such as i) 'agency theory' that refers to a majority of brands deciding to franchise their EBOs due to geographic dispersion required for the brand and suggests that the model helps brands to maximize their profit by allowing them to reduce the outlets monitoring costs while providing superior incentives to the franchisee; ii) 'resource scarcity theory' that refers to a majority of brands deciding to franchise EBOs due to capital constraints. However, there are three more theories of franchising in the literature such as i) transaction cost theory; ii) search cost theory; iii) signaling theory that has been tested by many studies, but has been said to be only complementary to the original two theories of franchising. Besides these five theories, we found Mishra, C.S.'s 'Theory of Franchising' to be most relevant for India in the $21^{\text {st }}$ century that was built on the 'theory of entrepreneurship' that emphasizes on the two-staged process of entrepreneurial value creation and develops firm and location-specific conditions under which a brand organization franchise [15-16]. Few studies have argued that the nature of the royalty fee that is paid by the franchisee to franchisor plays an important role concerning franchisee's motivation levels to achieve the franchisor's long-term business goals in addition to enhancing the franchisee's interest in the long-term business relationship with the franchisor. Various royalty fee systems that were studied and recommended are i) fixed royalty fee; ii) variable royalty fee; iii) combination of fixed and variable royalty fee; iv) dynamic royalty rates system [17-18]. As long as the franchisor has adapted automized systems to monitor inventory, accounting, sales, and consumer level transactional data, the number of franchisee EBOs to be added to the chain at territory, regional and national level is not a constraint for the franchisor and the only decision variable relevant would be the economies of scale [19].'Dual distribution system' that refers to a firm/organization/brand assigning contracts to agencies in a particular market to manage certain parts of its distribution channels/system has been one of the areas of interest among many researchers in addition to becoming one of the dominant distribution channel designs for a brand's marketing strategies, performance, and expansion [20-21]. There are two main models of operating a distribution channel in a particular market such as i) a vertically integrated model (VIS) that refers to a company owned and managed and ii) market-based channels that refer to franchisee owned and operated (MBS). A combination of VIS and 
MBS models is referred to as a 'dual distribution system (DDS)'.Many researchers have studied DDS using theories of contract such as agency theory and transaction cost economics theory argue that the system eliminates many problems that are associated with systems that are operated and monitored directly by the brand/organization/firm in addition to leading to greater efficiency under certain conditions [22-27]. There are advantages and disadvantages in adopting VIS model, MBS model and DDS model such as a) VIS model provides greater control over distribution channels [23-24]; b) lower costs and higher returns can be expected from MBS model [28-31]; c) MBS models provide the ability to respond to real-time needs of the market [32-34]; d) MBS models allow the brand to access new markets at lower costs and risks [35-36]; e) moral hazard problems are associated with MBS model [37-39]; f) income is uncertain in MBS model [40]; e) DDS model with its synergy component can help the brands to overcome a majority of disadvantages of both the VIS and MBS models [40-42].In addition to the model of franchising, royalty fee type, contract duration of franchise agreement/relationship is also an important attribute of the franchising. Key determinants of the franchise contract durations are a) transaction-specific investments; b) environmental uncertainty; c) strategic value creation available through knowledge leverage; d) intangible knowledge-based resources; e) intangible system-specific knowhow; f) brand name [43].

The Need for the Study: The prevailing assumption is that majority of lifestyle brands in India are bewildered with various theories, perspectives, and models available in the retailing expansion domain and hence, they are not able to design appropriate retailing expansion framework. There is a wide gap in the understanding of interlinkage between theories, perspectives, models, and frameworks available in the franchising domain which is globally accepted as one of the most economical ways of retailing expansion in a market. This gap can be reduced if we can demonstrate the correlation amongst various theories, perspectives, models, and frameworks available in the existing literature with the empirical pieces of evidence from India in this study and transpire the research outcomes into an integrated framework which would then be useful for lifestyle brands in India to design appropriate strategies concerning EBOs expansion. The need for this research indeed was originated due to various gaps found in theoretical, descriptive, empirical literature available in the retailing expansion domain such as a) a majority of studies have focussed on contractual attributes; b) a majority of studies have focussed on retailing in general and not specific to lifestyle retailing; c) absence of an integrated EBO expansion framework for lifestyle brands in the Indian context; d) a majority of lifestyle brands in India follow and practice EBO expansion frameworks incorporated by consumer goods, hospitality and restaurant brands and retailers, and, most importantly e) lifestyle brands in India are unable to expand their EBO presence owing to increasing realty costs and long-term capital investment requirements. The present study proposes to empirically understand various models adopted by lifestyle brands in India for EBO expansion, evaluate and design an integrated framework with the help of existing theories, models, and frameworks available in the literature.

\section{OBJECTIVES :}

Key objectives of this research were to, i) understand lifestyle brands market in India; ii) understand evolution and performance of Indian lifestyle brands; iii) understand the unit economics of different EBO types available; iv) understand existing EBOs mix of few select Indian lifestyle brands; v) analyze recommendations from previous research studies; vi) design and propose a tactical EBO expansion framework, and vii) recommend a systematic approach for executing the new framework.

\section{APPROACH AND METHODOLOGY :}

Secondary Research: Intense and in-depth analysis of data available in the public domain was carried to collect data relating to various aspects of lifestyle brands in India through company websites, company annual financial reports, Government database, trade, and business journals. Research works relating to Indian lifestyle brands were surveyed extensively to collect insights, recommendations, and frameworks to understand their existing EBO penetration and expansion plans in addition to an extensive review of models available for EBO expansion for lifestyle brands in India.

Qualitative Primary Research: Series of open-ended direct interviews were conducted with employees selected through convenience sampling representing different departments/functions from Brands, Distributors, Licensees and Franchisees viz., Key Business Accounts, Business Development, 
Store Expansion, Store Project, Strategy, Category, Communication, Customer Relationship, Warehousing, Finance, Information Technology, Training, Sales, Stores Operation along with Store Sales Personnel to understand their perspective and attitude towards existing EBO penetration and expansion models.

Quantitative Primary Research: In the first stage, a few lifestyle brands in India were selected who can represent, a) different product categories such as fashion, functional, life-stage specific, productspecific, gender-specific, and need specific products; b) offering single-product category and multipleproduct categories; c) serving different consumer target groups at low, mid-low, mid, mid-high, high, and premium price positioning; d) selling their products through local retailers either directly or using distributors, regional retailers either directly or using distributors, national retailers, EBOs operated directly by the brand, EBOs operated by the franchisee partners, online EBO store-operated either directly or using third parties and, online marketplaces; e) products manufactured from own factory and contract manufacturers (both inside and outside India); f) across developing brands, developed brands, and, established brands. In the second stage, 24 months' actual data was collected from these select lifestyle brands to quantitatively map their existing EBO penetration; performance; returns on investment; unit economics, and design an integrated framework to help lifestyle brands in India plan their EBO expansion economically and efficiently.

\section{KEY FINDINGS AND INSIGHTS :}

Qualitative: Before the empirical study, we were able to derive qualitative insights through mystery shopping and conduct open-ended direct interviews with employees and expansion partners representing all the departments/functions of lifestyle brands chosen for the study. Key insights from the qualitative survey indicate that the brand strongly had numerous beliefs and assumptions concerning company-owned and company-operated EBOs (COCO) and franchisee-owned and franchise-operated EBOs (FOFO).

Brand's(Franchisor) Perspective: a) It is very difficult to attract new consumers to COCO high street stores, b) lot of marketing money has to be spent to acquire new consumers to COCO high street stores, c) COCO high street stores need to have additional security cost, d) COCO high street stores maintenance becomes additional work for the store sales personnel, e) rent is higher in COCO high street stores, f) COCO mall stores help us create premium brand image in consumers mind, g) COCO mall stores attract lot of new consumers, h) marketing money spent for consumer acquisition is much lesser in COCO mall stores, i) COCO malls get huge consumer walk-ins/traffic, j) common area maintenance is taken care by the COCO mall management, $\mathrm{k}$ ) COCO mall stores have greater security systems, 1) COCO institutional stores do not generate significant revenue, $\mathrm{m}$ ) $\mathrm{COCO}$ institutional stores run only to acquire new consumers for other stores in the city, n) consumers treat COCO institutional stores for one-time purchases and most importantly o) consumers in the COCO mall stores are premium consumers and they tend to buy more compared to COCO high street and COCO institutional stores; p) COCO distribution channel is most capital intensive channel for the brand; q) unless the brand is known in the market, it is very difficult to attract franchisee to open FOFO stores; r) franchisee's interest is majorly skewed towards short-term return on investment (ROI) that dampen the long-term brand-building objectives; s) a majority of FOFO stores are in Tier-2 and Tier-3 cities as we are better in managing a COCO stores in Tier-1 cities; t) sales personnel training is a challenge at FOFO stores; u) a majority of FOFO store owners fail to demonstrate long-term vision; v) it is difficult to monitor sale of items not supplied by the brand in FOFO stores; w) a few FOFO store owners exited from the contract after a period of one year and started their own store as if they were trying to learn lifestyle retailing business using franchising route; $\mathrm{x}$ ) FOFO stores fail to generate higher revenue in comparison to COCO stores; y) a majority of the time FOFO stores inventory requirements are not aligned to national level requirements; z) FOFO stores are unable to sell high-priced items leading to the overall selling price of the store lower than COCO stores and most importantly a) senior management prefers FOFO over COCO store during expansion decisions owing to no capital investment and commitment required in FOFO.

Expansion Partner's (Franchisee) Perspective: a) Reputation of the brand plays an important role in franchise investment decision; b) it is very difficult to choose a brand as a majority of them have no unique differentiations; c) real debate is not on short-term and long-term vision, it is all about ROI and 


\section{International Journal of Case Studies in Business, IT, and Education SRINIVAS (IJCSBE), ISSN: 2581-6942, Vol. 4, No. 2, August 2020.

we refer to ROI to measure a brand's performance; d) franchisor's key interest is in having market penetration and a majority of the time not franchisee's ROI; e) brands run COCO stores in Tier-1 cities at premium locations and obviously COCO stores revenue is significantly higher than FOFO stores; $\mathrm{f}$ ) franchisor's pressure on us to increase the revenue by comparing FOFO stores in Tier-2 and 3 cities with their COCO stores in Tier-1 cities is inappropriate and a big demotivator for FOFO sales personnel; g) FOFO sales personnel are not treated equally compared to COCO sales personnel; $h$ ) franchisor always supply inventory which are on an average priced lower than their COCO stores; i) a majority of premium products are not supplied to FOFO stores as the franchisor assumes that the consumers in Tier-2 and Tier-3 cities have affordability issue; $j$ ) we do not understand the inventory as much as the franchisor understands, thus it is recommended that franchisor replaces the non-moving inventory with new inventory purely based on stock correction mode and most importantly k) franchisor's senior management teams level of communication with us reduces dramatically post the store-launch.

Empirical: Interestingly, when we evaluated actual data related to contracts, product assortment, sales, consumers, inventory level, inventory turns, product sell-through and velocity, rate of sales, revenue generation, profitability, unit economics, and ROI across COCO and FOFO stores we have found many insights which are contrary to what was believed by the lifestyle brands. In this sub-section we have classified empirical findings and insights by a) unit economics; b) ROI; c) decision-ownership; d) investment-ownership.

Unit Economics: The majority of lifestyle brands in the study were not well versed with the concept of 'unit economics'. Thus, we attempted to understand the unit economics of stores across COCO and FOFO models of lifestyle brands in the study which could enable us to understand the economical pros and cons of both the retailing models empirically rather than just looking at the qualitative pros and cons of these models. Table 1 shows the end to end the flow of parameters for a lifestyle EBO. It was also observed that most of these parameters were never tracked by the brands. Each of these parameters has been compared line by line between COCO and FOFOEBO models in addition to capturing the percentage variance in the FOFO model in comparison with the COCO model. Based on this comparison we have noted that COCOEBOs were superior in comparison to FOFOEBOs in parameters such as a) intake margin level higher by 27.27 percent; b) average product pricing higher by 4.67 percent; c) annualized inventory turns higher by 23.78 percent; d) quantity sold by almost double; e) sales per day per square foot higher by 7.50 percent; f) revenue higher by 57.05 percent and, g) gross earnings higher by 2.08 times. However, the discount level in COCO EBOs was 5.91 percentage points higher than FOFO stores in addition to COCO EBOs being located in premium locations at Tier-1 cities could have been a potential moderator for higher sales in COCO. Whereas, FOFOEBOs were superior in comparison to COCOEBOs in parameters such as a) optimal utilization of trading area higher by 46.09 percent owing to the common area loading being 1.60 times lesser; $b$ ) annualized discounts lower by 36.01 percent; c) store rental expenses lower by 2.97 times; d) store employee costs lower by 1.49 times; g) store overheads lower by 1.46 times; e) store-level EBITDA earning higher by 4.52times and most importantly f) net earnings for every unit of a product being sold to consumers being higher by 7.29times. These findings demonstrate that COCOEBOs even though generate higher revenue and gross margins in comparison to FOFO EBOs, are significantly poor in generating higher store-level profits despite 1.57 times higher revenue being generated at 2.08 times higher gross margin earnings, they generate 4.52 times lesser store-level profits. Retailing expenditures of COCOEBOs are significantly higher owing to their store location choice.

Returns on Investment: It was observed that the franchisee's performance evaluation attitude was more skewed towards evaluating their performance based on ROI in comparison with the brand. Most of the brand's key result areas (KRA) and key performance indicators (KPI) were skewed towards absolute revenue and percentage gross margin generated by the store whereas, only a few brands were tracking store-level EBITDA earnings. Table 2 captures key parameters that are detrimental in evaluating the ROI for COCO and FOFOEBOs in addition to indicating the percentage variance in the FOFO store model over a COCO store model. FOFO store model has shown a significant 5.85 times higher ROI compared to the COCO store model thereby making it easier for franchisees to recover the capital invested in launching a store significantly earlier than brands. 
Table 1: Store level unit economics and the variance among key parameters of COCO and FOFO EBOs for the same lifestyle brand

\begin{tabular}{|c|c|c|c|c|c|}
\hline \multirow[t]{2}{*}{ Particulars } & \multicolumn{2}{|c|}{$\begin{array}{c}\text { EBO } \\
\text { COCO Stores }\end{array}$} & \multicolumn{2}{|c|}{$\begin{array}{c}\text { EBO } \\
\text { FOFO Stores }\end{array}$} & \multirow[t]{2}{*}{ Variance } \\
\hline & Value & $\%$ of Revenue & Value & $\%$ of Revenue & \\
\hline Trading Area $(S F T)$ & 1500 & $\mathrm{Na}$ & 1150 & $\mathrm{Na}$ & $-30.43 \%$ \\
\hline Common Area Loading (\%) & $40.00 \%$ & $\mathrm{Na}$ & $25.00 \%$ & $\mathrm{Na}$ & $-60.00 \%$ \\
\hline Carpet Area $(S F T)$ & 2100 & $\mathrm{Na}$ & 1438 & $\mathrm{Na}$ & $-46.09 \%$ \\
\hline Average MRP (INR) & 762 & $\mathrm{Na}$ & 728 & $\mathrm{Na}$ & $-4.67 \%$ \\
\hline Intake Margin on MRP & $70.00 \%$ & $\mathrm{Na}$ & $55.00 \%$ & $\mathrm{Na}$ & $-27.27 \%$ \\
\hline Average Product Base Cost (INR) & 229 & $\mathrm{Na}$ & 328 & $\mathrm{Na}$ & $30.22 \%$ \\
\hline Minimum Display Inventory Value at MRP (INR Lacs) & 91.44 & $715.47 \%$ & 66.98 & $823.02 \%$ & $-36.53 \%$ \\
\hline Minimum Display Inventory Value at Cost (INR Lacs) & 27.43 & $214.64 \%$ & 30.14 & $370.36 \%$ & $8.98 \%$ \\
\hline Annual Inventory Turns & 2.29 & $17.92 \%$ & 1.85 & $14.48 \%$ & $-23.78 \%$ \\
\hline Sales Quantity (Pieces per Month) & 2290 & $\mathrm{Na}$ & 1418 & $\mathrm{Na}$ & $-61.46 \%$ \\
\hline Return Sales Quantity (Pieces per Month) & 23 & $\mathrm{Na}$ & 14 & $\mathrm{Na}$ & $-61.46 \%$ \\
\hline Net Sales Quantity (Pieces per Month) & 2267 & $\mathrm{Na}$ & 1404 & $\mathrm{Na}$ & $-61.46 \%$ \\
\hline Sales MRP Value (INR Lacs per Month) & 17.28 & $135.17 \%$ & 10.22 & $125.61 \%$ & $-69.00 \%$ \\
\hline Annualized Dis count (\%) & $22.32 \%$ & $\mathrm{Na}$ & $16.41 \%$ & $\mathrm{Na}$ & $-36.01 \%$ \\
\hline Dis count Value (INR Lacs per Month) & 3.86 & $30.17 \%$ & 1.68 & $20.61 \%$ & $-129.86 \%$ \\
\hline Gross Sales Value (INR Lacs per Month) & 13.42 & $105.00 \%$ & 8.54 & $105.00 \%$ & $-57.05 \%$ \\
\hline Average Selling Price (INR per Piece) & 592 & $\mathrm{Na}$ & 609 & $\mathrm{Na}$ & $2.73 \%$ \\
\hline $\mathrm{SPF}(I N R)$ & 21.30 & $\mathrm{Na}$ & 19.81 & $\mathrm{Na}$ & $-7.50 \%$ \\
\hline Secondary Tax $(\%)$ & $5 \%$ & $0.39 \%$ & $5 \%$ & $0.61 \%$ & $0.00 \%$ \\
\hline Secondary Tax Value (INR Lacs per Month) & 0.64 & $5.00 \%$ & 0.41 & $5.00 \%$ & $-57.05 \%$ \\
\hline Revenue (INR Lacs per Month) & 12.78 & $100.00 \%$ & 8.14 & $100.00 \%$ & $-57.05 \%$ \\
\hline Cost of Goods Sold (INR Lacs per Month) & 5.18 & $40.55 \%$ & 4.60 & $56.53 \%$ & $-12.67 \%$ \\
\hline Gross Earning Value (INR Lacs per Month) & 8.24 & $64.45 \%$ & 3.94 & $48.47 \%$ & $-108.81 \%$ \\
\hline Gross Earning (\%) & $61 \%$ & $\mathrm{Na}$ & $46 \%$ & $\mathrm{Na}$ & $-32.96 \%$ \\
\hline $\operatorname{MPF}(I N R)$ & 13.07 & $\mathrm{Na}$ & 9.15 & $\mathrm{Na}$ & $-42.93 \%$ \\
\hline Rent per SFT (INR per Month) & 135 & $\mathrm{Na}$ & 68 & $\mathrm{Na}$ & $-98.53 \%$ \\
\hline Store Rent Value (INR Lacs per Month) & 2.84 & $22.18 \%$ & 0.98 & $12.01 \%$ & $-190.03 \%$ \\
\hline CAM per SFT (INR per Month) & 12.98 & $\mathrm{Na}$ & 4.80 & $\mathrm{Na}$ & $-170.42 \%$ \\
\hline Store CAM Value (INR Lacs per Month) & 0.27 & $2.13 \%$ & 0.07 & $0.85 \%$ & $-295.04 \%$ \\
\hline SFT Covered by One Sales Personnel & 300 & $\mathrm{Na}$ & 300 & $\mathrm{Na}$ & $0.00 \%$ \\
\hline Sales Personnel Head Count & 7 & $\mathrm{Na}$ & 5 & $\mathrm{Na}$ & $-46.09 \%$ \\
\hline Store Managers Head Count & 1 & $\mathrm{Na}$ & 1 & $\mathrm{Na}$ & $0.00 \%$ \\
\hline Store House Keeping Personnel Head Count & 1 & $\mathrm{Na}$ & 1 & $\mathrm{Na}$ & $0.00 \%$ \\
\hline Store Security Personnel Head Count & 1 & $\mathrm{Na}$ & 0 & $\mathrm{Na}$ & $0.00 \%$ \\
\hline Total Employee Cost (INR Lacs per Month) & 1.48 & $11.58 \%$ & 0.99 & $12.15 \%$ & $-49.68 \%$ \\
\hline Store Overheads per SFT (INR per Month) & 54.68 & $\mathrm{Na}$ & 54.68 & $\mathrm{Na}$ & $0.00 \%$ \\
\hline Store Overheads Cost (INR Lacs per Month) & 1.15 & $8.98 \%$ & 0.79 & $9.66 \%$ & $-46.09 \%$ \\
\hline Bank and Finance Charges (INR Lacs per Month) & 0.20 & $1.58 \%$ & 0.13 & $1.58 \%$ & $-57.05 \%$ \\
\hline Brand Promotional Cost (INR Lacs per Month) & 0.94 & $7.35 \%$ & 0.00 & $0.00 \%$ & $0.00 \%$ \\
\hline Warehousing Expenses (INR Lacs per Month) & 0.51 & $4.00 \%$ & 0.16 & $2.00 \%$ & $-214.10 \%$ \\
\hline Logistics Expenses (INR Lacs per Month) & 0.51 & $4.00 \%$ & 0.00 & $0.00 \%$ & $0.00 \%$ \\
\hline Shrinkage (INR Lacs per Month) & 0.168 & $1.31 \%$ & 0.064 & $0.79 \%$ & $-161.75 \%$ \\
\hline Total Retailing Cost (INR Lacs per Month) & 8.07 & $63.12 \%$ & 3.18 & $39.03 \%$ & $-153.97 \%$ \\
\hline EBITDA Value (INR Lacs per Month) & 0.17 & $1.33 \%$ & 0.77 & $9.44 \%$ & $77.86 \%$ \\
\hline EBITDA (\%) & $1.33 \%$ & $\mathrm{Na}$ & $9.44 \%$ & $\mathrm{Na}$ & $85.90 \%$ \\
\hline Net Earnings per Piece Sold (INR) & 7.43 & $\mathbf{N a}$ & 54.18 & $\mathbf{N a}$ & $86.28 \%$ \\
\hline
\end{tabular}

Decision-Ownership: It was observed that the decision-making and ownership across many key elements of Marketing Mix were held with the franchisee that could be attributed to the overall contract terms which were prominently skewed in favor of the lifestyle brand. Table 3 depicts the mapping of existing decision-making and ownership across key decision-making areas. 
Table 2: Returns on investment (ROI) and the variance among COCO and FOFO EBOs of the same lifestyle brand

\begin{tabular}{|l|r|r|r|}
\hline Particulars & $\begin{array}{r}\text { EBO } \\
\text { COCO Stores }\end{array}$ & $\begin{array}{r}\text { EBO } \\
\text { FOFO Stores }\end{array}$ & Variance \\
\hline Trading Area (SFT) & 1500 & 1150 & $-30.43 \%$ \\
\hline Common Area Loading (\%) & $40.00 \%$ & $25.00 \%$ & $-60.00 \%$ \\
\hline Carpet Area (SFT) & 2100 & 1438 & $-46.09 \%$ \\
\hline First Time Investment on Inventory (INR Lacs) & 27.43 & 30.14 & $8.98 \%$ \\
\hline One-Time Interiors and Store Set Up Cost per SFT & 2500.00 & 2125.00 & $-17.65 \%$ \\
\hline One-Time Interiors and Store Set Up Cost (INR Lacs) & 52.50 & 30.55 & $-71.87 \%$ \\
\hline One-Time Franchis ing Fee (INR Lacs) & 0.00 & 1.00 & $100.00 \%$ \\
\hline Realty Partner's Refundable Security Deposit (INR Lacs) & 8.51 & 2.93 & $-190.03 \%$ \\
\hline Total Capital Requirement per Store (INR Lacs) & 88.44 & 64.62 & $-36.86 \%$ \\
\hline Total Operating Expenses per Anum (INR Lacs) & 96.80 & 38.12 & $-153.97 \%$ \\
\hline Total EBITDA Earning per Anum (INR Lacs) & 2.04 & 9.22 & $77.86 \%$ \\
\hline Returns on Inves tment at Store Level (\%) & $\mathbf{2 . 5 5 \%}$ & $\mathbf{1 4 . 9 5 \%}$ & $\mathbf{8 2 . 9 1 \%}$ \\
\hline Number of Years Required to Recover Capital Invested & 39.14 & 6.69 & $-485.15 \%$ \\
\hline
\end{tabular}

Table 3: Decision-ownership mapping across key decision areas for COCO and FOFO EBOs of the same lifestyle brand (existing)

\begin{tabular}{|c|c|c|c|}
\hline \multirow{2}{*}{$\begin{array}{l}\text { Marketing } \\
\text { Mix Element }\end{array}$} & \multirow{2}{*}{ Key Decision Area } & \multicolumn{2}{|c|}{ Decision Ownership } \\
\hline & & COCO & FOFO \\
\hline Place (P4) & Store Location Choice & B & $\mathrm{B} \& \mathrm{~F}$ \\
\hline Place (P4) & Store Size Choice & $\mathrm{B}$ & $\mathrm{B} \& \mathrm{~F}$ \\
\hline Place (P4) & Store Exteriors & B & B \\
\hline Place (P4) & Store Interiors & B & B \\
\hline Product $(\mathrm{P} 1)$ & Product/Category Assortment & $\mathrm{B}$ & B \\
\hline Place (P4) & Visual Merchandising & $\mathrm{B}$ & B \\
\hline People (P0) & Hiring - Store Manager & $\mathrm{B}$ & $\mathrm{F}$ \\
\hline People (P0) & Hiring - Sales Personnel & $\mathrm{B}$ & $\mathrm{F}$ \\
\hline People (P0) & Training of Store Team & $\mathrm{B}$ & $\mathrm{B} \& \mathrm{~F}$ \\
\hline Product $(\mathrm{P} 2)$ & Product Pricing & B & B \\
\hline Promotion (P3) & Store-Level Promotions & $\mathrm{B}$ & $\mathrm{F}$ \\
\hline Promotion (P3) & Catchment-Level Promotions & $\mathrm{B}$ & $\mathrm{F}$ \\
\hline Promotion (P3) & Product-Level Discounts & B & $\mathrm{F}$ \\
\hline
\end{tabular}

$B$ - Lifestyle Brand; F - Franchisee

Investment-Ownership: Table 4 depicts the mapping of existing investment areas across $\mathrm{COCO}$ and FOFO models. It is noted that almost all the investments were supposedly made by the franchisee on behalf of the lifestyle brand and prominently skewed in favor of the lifestyle brand.

\section{EBO EXPANSION FRAMEWORK (EBOE-LS) :}

Both qualitative and empirical findings unanimously indicate that the existing strategy of EBO expansion of select lifestyle brands is predominantly skewed in favor of the brand in addition to passing on a majority of investment risk onto expansion partners when franchised (FOFO) and predominantly skewed towards premium locations and cities when managed by themselves (COCO). It is a universally known phenomenon that unless a business model has a balanced risk-mitigation and profit model among its key investors it is unlikely to be a long-term business strategy. It is not economically viable for a lifestyle brand to open COCO stores as the same is capital intensive that indirectly proposes to partner with small-scale investors at store-level for expanding EBOs. Lifestyle brands need to understand their key objective of partnering with external small-scale investors and if the key objective is to expand EBOs presence across the country with minimal capital investment, maximum market- 


\section{International Journal of Case Studies in Business, IT, and Education SRINIVAS (IJCSBE), ISSN: 2581-6942, Vol. 4, No. 2, August 2020.

knowledge gain and quick market penetration then designing an appropriate framework for EBOs expansion are necessary that would protect both brand image and investors interest in addition to providing a long-term strategical and competitive advantage. In addition to borrowing insights from key theories of franchising such as a) agency theory; b) resource scarcity theory; c) Mishra, C. S.'s Theory of Franchising [15] and three models of operating a distribution channel in a particular market such as a) vertically-integrated model; b) market-based channels; c) dual-distribution systems [25-42], we believe that the basic "4P's" Marketing Mix proposition which was originally framed by McCarthy sixty years ago is still relevant and has a significant influence on framing decision-making/ownership allocation between a lifestyle brand and the franchisee in the Indian context [44].

Table 4: Investment-ownership mapping across key investment areas for COCO and FOFO EBOs of the same lifestyle brand (existing)

\begin{tabular}{|l|c|c|}
\hline \multirow{2}{*}{ Key Investment Area } & \multicolumn{2}{|c|}{ Investor } \\
\hline Store Exteriors Cost & COCO & FOFO \\
\hline Store Interiors Cost & $\mathrm{B}$ & $\mathrm{F}$ \\
\hline Inventory Cost & $\mathrm{B}$ & $\mathrm{F}$ \\
\hline Employee Cost & $\mathrm{B}$ & $\mathrm{F}$ \\
\hline Training Cost & $\mathrm{B}$ & $\mathrm{F}$ \\
\hline Store-Level Promotions Cost & $\mathrm{B}$ & $\mathrm{F}$ \\
\hline Catchment-Level Promotions Cost & $\mathrm{B}$ & $\mathrm{F}$ \\
\hline Product-Level Discounts Cost & $\mathrm{B}$ & $\mathrm{F}$ \\
\hline Inventory Liquidation Cost & $\mathrm{B}$ & $\mathrm{F}$ \\
\hline Store Rent & $\mathrm{B}$ & $\mathrm{F}$ \\
\hline Store CAM & $\mathrm{B}$ & $\mathrm{F}$ \\
\hline Store Overheads & $\mathrm{B}$ & $\mathrm{F}$ \\
\hline Finance Interest Cost & $\mathrm{B}$ & $\mathrm{F}$ \\
\hline Logistics Cost & $\mathrm{B}$ & $\mathrm{F}$ \\
\hline Warehousing Cost & $\mathrm{B}$ & $\mathrm{B}$ \\
\hline B & $\mathrm{B}$ & $\mathrm{F}$ \\
\hline
\end{tabular}

B - Lifestyle Brand; F - Franchisee

In addition to modifying the decision-making, decision-ownership, and investment areas of the existing COCO and FOFO models, we have introduced one more model that is 'franchisee-owned companyoperated (FOCO)' as depicted in tables 5 and 6. FOCO has been created to ensure a perfect balance of investment risk-mitigation and retailing profit between a lifestyle brand and an expansion partner. In the FOCO model, the lifestyle brand, and the expansion partner (franchisee) will have equal responsibility in creating a true image of the brand in employees, investors, competitors, and consumer's minds. Areas in which we have mentioned F \& B does recommend an equal sharing between the brand and the franchisee.

Among COCO, FOFO and FOCO EBO models, Framework 1 indicates the recommended mapping of each of these EBO expansion models to be deployed that are efficient and economical concerning different types of cities such as i) Tier-1 (for example: Delhi and NCR, Kolkata, Mumbai, Chennai, Bengaluru and Hyderabad, etc.); ii) Tier-2 (for example: Agra, Ajmer, Aligarh, Amritsar, Asansol, Aurangabad, Bareilly, Bhavnagar, Bhiwandi, Bhopal, Bhubaneswar, Bikaner, Salem, Tiruchirappalli, Chandigarh, Coimbatore, Cuttack, Dehradun, Dhanbad, Erode, Gwalior, Durgapur, Faridabad, Firozabad, Ghaziabad, Gulbarga, Guntur, Guwahati, Hubli-Dharwad, Indore, Jabalpur, Jaipur, Jalandhar, Jammu, Jamnagar, Jamshedpur, Jhansi, Jodhpur, Kannur, Kakinada, Kochi, Kota, Kozhikode, Kurnool, Lucknow, Ludhiana, Madurai, Malappuram, Mathura, Mangalore, Meerut, Moradabad, Mysore, Nagpur, Nanded, Nashik, Nellore, Pune, Palakkad, Patna, Pondicherry, Raipur, Rajkot, Siliguri, Rajahmundry, Ranchi, Rourkela, Srinagar, Thrissur, Tirunelveli, Tirupur, 


\section{International Journal of Case Studies in Business, IT, and Education SRINIVAS (IJCSBE), ISSN: 2581-6942, Vol. 4, No. 2, August 2020.

Tiruvannamalai, Ujjain, Vadodara, Varanasi, Vellore, Vijayawada, Visakhapatnam, Vasai-Virar City, Warangal and New Mumbai, etc.); iii) Tier-3 (All other cities not part of Tier-1 and Tier-2) [10], and different location types such as i) Mall (example: large commercial complexes and malls); ii) High Street (example: central market area); iii) Neighborhood (example: residential area); iv) Institutional (example: designated shopping area in larger campuses, tech parks, resorts, hospitals and apartments) [12].

Table 5: Decision-ownership mapping across key decision areas for COCO, FOCO and FOFO EBOs of for lifestyle brand(proposed)

\begin{tabular}{|l|l|c|c|c|}
\hline \multirow{2}{*}{$\begin{array}{l}\text { Marketing } \\
\text { Mix Element }\end{array}$} & Key Decision Area & \multicolumn{3}{|c|}{ Decision Ownership } \\
\hline Place (P4) & Store Location Choice & B & F \& B & F \\
\hline Place (P4) & Store Size Choice & B & F \& B & F \\
\hline Place (P4) & Store Exteriors & B & B & B \\
\hline Place (P4) & Store Interiors & B & B & B \\
\hline Product (P1) & Product/Category Assortment & B & B & B \\
\hline Place (P4) & Visual Merchandising & B & B & B \\
\hline People (P0) & Hiring - Store Manager & B & B & B \\
\hline People (P0) & Hiring - Sales Personnel & B & B & B \\
\hline People (P0) & Training of Store Team & B & B & B \\
\hline Product (P2) & Product Pricing & B & B & B \\
\hline Promotion (P3) & Store-Level Promotions & B & F \& B & F \\
\hline Promotion (P3) & Catchment-Level Promotions & B & F \& B & F \\
\hline Promotion (P3) & Product-Level Discounts & B & B & B \\
\hline
\end{tabular}

$B$ - Lifestyle Brand; F - Franchisee

A significant and positive association with a strong determination between sales personnel's consumer orientation level and the consumer repeat visit rate to a store was found in a few of our earlier experimental studies. This indicates that lifestyle brands/retailers need to give utmost importance to a) the number of sales personnel in a store; $b$ ) sales personnel performance measurement methods; $c$ ) empowerment level of sales personnel; d) sales personnel's overall development in addition to utilizing them as brand ambassadors that would be most efficient and economical [45-50]. Thus, in the proposed framework we have given equal ownership of decisions concerning sales personnel in a franchised store irrespective of the level of investment being made by the franchisee. We determinedly followed the integrated Marketing Mix framework for lifestyle brands [7] and retailers [52] in India that was developed by us in the previous experimental/empirical studies to design EBOE-LS framework and mapped decision-making/ownership of key elements of Marketing Mix to the lifestyle brand rather than the franchisee irrespective of the model recommended for deployment.

\section{CONCLUSION :}

While designing the EBOE-LS framework we have followed a logical mixture of existing theories in the literature such as a) Theory of Marketing Mix [44]; b) Theory of Franchising [15]; c) Theory of Dual Distribution System[40-42] in addition to borrowing recommendations and insights from experimental/empirical studies that were carried out by us in the Indian context [7] [10-12] [45-53]. Amongst all the distribution channels available in India EBO is the only channel that enables lifestyle brands to understand, interact, and maintain a long-term relationship with their consumers better than any other channel. EBO also help lifestyle brands to communicate real-time offerings of the brand across products and promotions in addition to having higher possibilities of showing the real brand experience to consumers. Notwithstanding huge capital investment and commitment for the lifestyle brand, EBO stores probably add more value to the brand on overall brand image in employees, investors, competitors, and consumer's mind as the majority of the variables directly impact overall 


\section{International Journal of Case Studies in Business, IT, and Education SRINIVAS (IJCSBE), ISSN: 2581-6942, Vol. 4, No. 2, August 2020. \\ PUBLICATION}

brand profitability at store level are controlled by the lifestyle brand itself which is not the case in other distribution channels available for lifestyle brands in India. The rational distribution channel mix if executed efficiently can also possibly attract many new investors in the form of Franchisees who can help the brand is expanding its presence across the country through EBO stores at very minimal or no capital investment and commitment involved [11]. It is inevitable for a lifestyle brand India to have a strong/wider presence of EBOs across the country. However, we refrain from recommending any lifestyle brand in India to adopt EBO expansion strategies that are significantly skewed towards COCO models in addition to refraining from recommending them to adopt EBO expansion strategies that tend to use FOFO model that is significantly skewed in favor of the brand which does not consider the longterm impact of such contracts on the overall brand's image. The proposed EBOE-LS framework thus incorporates advantages of COCO and FOFO models, reduces potential disadvantages by adding in one more model named FOCO, and recommends appropriate deployment of these three models of EBO expansion based on city tier and the store location type.

Table 6: Investment-mapping across key investment areas for COCO, FOFO, and FOCOEBOs for lifestyle brand (proposed)

\begin{tabular}{|l|c|c|c|}
\hline \multirow{2}{*}{ Key Investment Area } & \multicolumn{3}{|c|}{ Investor } \\
\hline Store Exteriors Cost & COCO & FOCO & FOFO \\
\hline Store Interiors Cost & B & F & F \\
\hline Inventory Cost & B & F & F \\
\hline Employee Cost & B & F \& B & F \& B \\
\hline Training Cost & B & B & F \\
\hline Store-Level Promotions Cost & B & F \& B & F \& B \\
\hline Catchment-Level Promotions Cost & B & F \& B & F \& B \\
\hline Product-Level Discounts Cost & B & F \& B & F \& B \\
\hline Inventory Liquidation Cost & B & F \& B & F \& B \\
\hline Store Rent & B & F \& B & F \& B \\
\hline Store CAM & B & F \& B & F \\
\hline Store Overheads & B & F \& B & F \\
\hline Finance Interest Cost & B & F \& B & F \\
\hline Logistics Cost & B & F & F \\
\hline Warehousing Cost & B & F & F \\
\hline B - Lifestye Brand; F Franc| & B & F & F \\
\hline
\end{tabular}

B - Lifestyle Brand; F - Franchisee

\section{SUGGESTIONS :}

The sustainable success of a lifestyle brand in India significantly depends on the trueness level of their image that is carried in consumers' minds and not the revenue or profit they generate. To ensure a lifestyle brand gets a true lifestyle image in consumers' minds, they need to think beyond revenue and profit which is what has to be the main criteria while deciding on the EBOs expansion strategies. Unless a lifestyle brand provides a uniform experience across cities, locations, distribution channels and types of EBOs (COCO/FOFO/FOCO), it is unlikely that the brand will ever be able to create a positive image in consumer's minds in addition to creating a higher number of consumers with high levels of patronage with the brand. Lifestyle brands in India also need to clearly understand every other lifestyle brand's key business objectives behind having COCO EBOs that are more expensive to operate; few brands may be trying to show exponential growth in their revenue to attract more investors by opening COCO EBOs quickly at premium locations and Tier-1 cities; few brands may be trying to create different perceptions in consumers mind over their brand image; few brands may be opening many EBOs in 


\section{International Journal of Case Studies in Business, IT, and Education $\quad$ SRINIVAS (IJCSBE), ISSN: 2581-6942, Vol. 4, No. 2, August 2020. PUBLICATION}

premium locations with larger size to tag them as experiential, anchor or destination stores assuming that this effort would lead them to create a premium brand image in consumers, competitors and investors mind and could attract franchisees; few brands may be expanding their presence in catchment areas irrespective of their target consumer groups to promote their brand to attract new investors; few conglomerates may be trying to show their presence in the lifestyle brand segment to strengthen their group portfolio and so on. What is very important is the key business goal of your brand, your target consumer group, target consumer group's attitude towards your EBOs, and most importantly your aim to establish a true lifestyle brand image in employees, investors, competitors, and consumers mind. Finally, we would suggest lifestyle brands in India to design fair and balanced frameworks for their EBOs expansion keeping the long-term business objectives in mind.

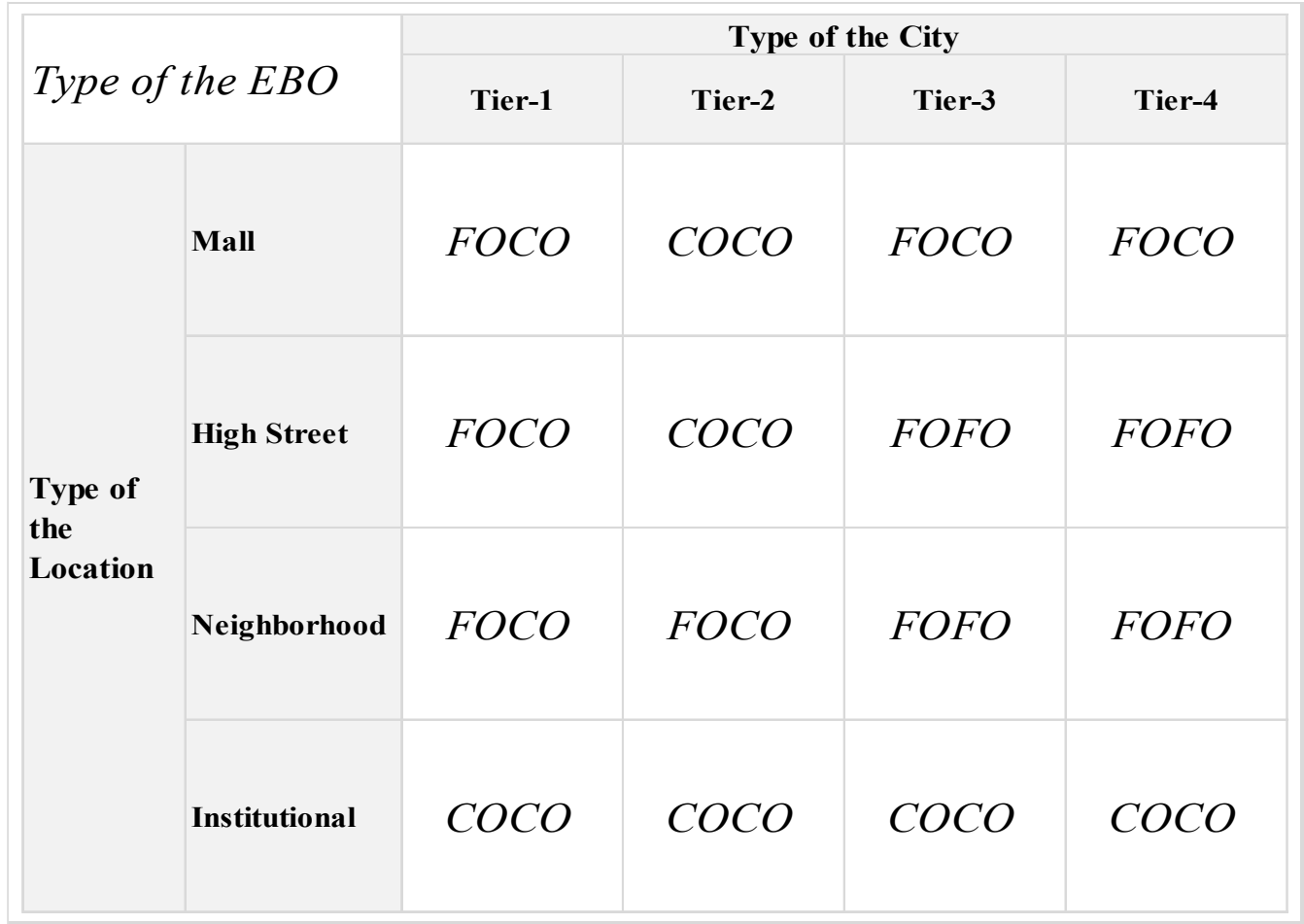

Framework 1: Integrated EBOs expansion framework for lifestyle brands in India (EBOE-LS)

\section{LIMITATIONS OF RESEARCH :}

The main limitation of this research work is the coverage of various stakeholders viz., the number of lifestyle brands, product categories, consumer groups, employees, price positioning, EBO expansion partners, and types of EBO expansion methods while designing the recommended EBOE-LS framework. This might limit the generalizability of research findings to other sets of lifestyle brands. The second limitation would be the empirical validation is restricted to a few Indian lifestyle brands selected for the study and hence the generalizability of the findings and suggestions to other Indian lifestyle brands. The third limitation would be our ability to experiment, though we were firm in our approach that, the proposed EBOE-LS framework has to be tested in the field before we recommend it. It was not that easy merely because of the vast scope of the experiment. Unlike other experiments wherein the treatment is limited to few concepts, components or variables this experiment required us to cover practically almost all the elements of the lifestyle brand's Marketing Mix which do require longer duration for preparations before testing, longer duration before the beginning of extracting the results and a longer period for the experimentation itself to ensure findings and insights are derived holistically. However, EBOE-LS provides significant input regarding how Indian lifestyle brands could utilize these recommendations to start their journey towards becoming a 'true lifestyle brand' in a sustainably profitable manner across the country with minimal capital investment and quick market penetration as the recommendations are based on our research findings of similar experiments and 


\section{International Journal of Case Studies in Business, IT, and Education $\quad$ SRINIVAS (IJCSBE), ISSN: 2581-6942, Vol. 4, No. 2, August 2020. \\ PUBLICATION}

empirical studies relevant for lifestyle brands in the Indian context in addition to proven theories in the literature.

\section{SCOPE FOR FURTHER RESEARCH :}

We strongly recommended that the EBOE-LS framework is used by researchers to further test its validity and reliability in addition to finetuning it further if required for lifestyle or non-lifestyle brands and retailers. Based on short-term and long-term the key business objectives of lifestyle brands/retailers, the EBOE-LS framework can be used as a basic tool while deploying various types of EBO expansion models and finetune the framework suitably.

\section{REFERENCES :}

[1] Schmitt, B. (2012). The consumer psychology of brands. Journal of Consumer Psychology.22 (1), $7-17$.

[2] http://www.technopak.com/Files/fashion-retail-scenario-in-india.pdf. Retrieved in July 2020.

[3] http://statisticstimes.com/demographics/population-of-india.php. Retrieved in July 2020.

[4] https://www.mckinsey.com/industries/retail/our-insights/the-state-of-fashion-2019-a-year-ofawakening. Retrieved in July 2020.

[5] https://www2.deloitte.com/content/dam/Deloitte/in/Documents/consumer-business/in-consumerRLS-2019-noexp.pdf. Retrieved in July 2020.

[6] https://www.amazon.in/b/?ie=UTF8\&node=6648217031\&ref_topnav_storetab_top_ap_mega. Retrieved in July 2020.

[7] Ganesha, H. R. \& Aithal, P. S. (2020). Establishing True Lifestyle Brand in India: An Integrated Marketing Mix Framework. International Journal of Management, Technology, and Social Sciences (IJMTS), 5(1), 261-284.

[8] https://www.ibef.org/industry/real-estate-india.aspx. Retrieved in July 2020.

[9] https://www.mckinsey.com/featured-insights/urbanization/urban-awakening-in-india. Retrieved in July 2020.

[10] Ganesha, H. R., Aithal, P. S. \& Kirubadevi, P. (2020). Consumer Affordability in Tier-1, Tier-2, and Tier-3 Cities of India - An Empirical Study. International Journal of Applied Engineering and Management Letters (IJAEML),4(1), 156-171.

[11] GaneshaH. R.\& Aithal, P. S. (2020). Rational Distribution Channel Mix for Lifestyle Brands in India - An Empirical Study. International Journal of Case Studies in Business, IT, and Education (IJCSBE), 4(1), 136-154.

[12] Ganesha, H. R., Aithal, P. S. \& Kirubadevi, P. (2020). Ideal Store Locations for Indian Retailers An Empirical Study. International Journal of Management, Technology, and Social Sciences (IJMTS), 5(1), 215-226.

[13] Rubin, P. H. (1978). The theory of the firm and the structure of the franchise contract. Journal of Law and Economics, 21, 223-234.

[14] Bradach, J. L. (1997). Using the plural form in the management of restaurant chains. Administrative Science Quarterly, 42, 276-303.

[15] Mishra, C. S. (2017). The theory of Franchising. In Creating and Sustaining Competitive Advantage,307-355. Palgrave Macmillan, Cham.

[16] Mishra, C. S., \& Zachary, R. K. (2014). The theory of entrepreneurship: Creating and sustaining entrepreneurial value. New York: Palgrave Macmillan.

[17] Tikoo, S.,\& Nair, S. (1999). Variable royalty rates for improving franchise channel coordination. Decision Sciences, 30(2), 469-479. 
[18] Nwogugu, M. I. (2019). On Franchise Royalty Rates, Franchise Fees and Incentive Effects. In Complex Systems, Multi-Sided Incentives and Risk Perception in Companies.507-536. Palgrave Macmillan, London.

[19] Chiu, Y., \& Hu, J. (2003). Payment types and number of franchisees. The Service Industries Journal, 23(4), 42-60.

[20] Anderson, E., Day, G. S., \& Rangan, V. K. (1997). Strategic channel design. MIT Sloan Management Review, 38(4), 59-69.

[21] Stern, L. W., \& Weitz, B. A. (1997). The revolution in distribution: challenges and opportunities. Long Range Planning, 30(6), 823-829.

[22] Bergen, M., Dutta, S., \& Walker Jr, O. C. (1992). Agency relationships in marketing: A review of the implications and applications of agency and related theories. Journal of Marketing, 56(3), 124.

[23] Dutta, S., Bergen, M., Heide, J. B., \& John, G. (1995). Understanding dual distribution: the case of reps and house accounts. Journal of Law, Economics, \& Organization, April,189-204.

[24] Heide, J. B. (1994). Interorganizational governance in marketing channels. Journal of Marketing, 58(1), 71-85.

[25] John, G., \& Weitz, B. A. (1988). Forward integration into distribution: an empirical test of transaction cost analysis. Journal of Law, Economics, and Organization, 4, 337.

[26] Rindfleisch, A., \& Heide, J. B. (1997). Transaction cost analysis: Past, present, and future applications. Journal of Marketing, 61(4), 30-54.

[27] Heide, J. B. (2003). Plural governance in industrial purchasing. Journal of Marketing, 67(4), 1829.

[28] Alchian, A. A., \& Demsetz, H. (1972). Production, information costs, and economic organization. The American Economic Review, 62(5), 777-795.

[29] Grossman, S. J., \& Hart, O. D. (1986). The costs and benefits of ownership: A theory of vertical and lateral integration. Journal of Political Economy, 94(4), 691-719.

[30] Jensen, M. C., \& Meckling, W. H. (1979). Theory of the firm: Managerial behavior, agency costs, and ownership structure. In Economics Social Institutions, 163-231. Springer, Dordrecht.

[31] Lafontaine, F., \& Shaw, K. L. (2005). Targeting managerial control: evidence from franchising. RAND Journal of Economics, April,131-150.

[32] Bradach, J. L. (1998). Franchise organizations. Harvard Business Press. P 127.

[33] Yin, X., \& Zajac, E. J. (2004). The strategy/governance structure fit relationship: Theory and evidence in franchising arrangements. Strategic Management Journal, 25(4), 365-383.

[34] Lewin-Solomons, S. B. (2000). The plural form in franchising: A synergism of market and hierarchy, December (No. 0027), Faculty of Economics, University of Cambridge.

[35] Dahlstrom, R. \& Nygaard, A. (1994). A preliminary investigation of franchised oil distribution in Norway. Journal of Retailing, 70(2), 179-191.

[36] Brickley, J. A., \& Dark, F. H. (1987). The choice of organizational form the case of franchising. Journal of Financial Economics, 18(2), 401-420.

[37] Blair, R. D. \& Kaserman, D. L. (1994). A note on incentive incompatibility under franchising. Review of Industrial Organization, 9(3), 323-330.

[38] Fama, E. F. \& Jensen, M. C. (1983). Agency problems and residual claims. The Journal of Law and Economics, 26(2), 327-349. 
[39] A. Oxenfeldt.\&Kelly, A. O. (1969). Will Successful Franchise Systems Ultimately BecomeWhollyOwned Chains? Journal of Retailing, 44, 69-83.

[40] Bradach, J. L. (1997). Using the plural form in the management of restaurant chains. Administrative Science Quarterly, June, 276-303.

[41] Martin, R. E. (1988). Franchising and risk management. The American Economic Review, December, 954-968.

[42] Lafontaine, F. \& Kaufmann, P. J. (1994). The evolution of ownersip patterns in franchise systems. Journal of Retailing, 70(2), 97-113.

[43] Gorovaia, N. \& Windsperger, J. (2018). The choice of contract duration in franchising networks: A transaction cost and resource-based view. Industrial Marketing Management, 75, November, 125-133.

[44] McCarthy, E. J. (1960). Basic marketing: a managerial approach. Homewood, Illinois: Richard D. Irwin. Inc. McCarthy Basic Marketing: A Managerial Approach 1960,24-95.

[45] Ganesha, H. R., Aithal, P. S. \& Kirubadevi, P. (2020). An Integrated Framework to Derive Optimal Number of Sales Personnel for a Retail Store. International Journal of Applied Engineering and Management Letters (IJAEML),4(1), 41-50.

[46] Ganesha, H. R., Aithal, P. S. \& Kirubadevi, P. (2020). Input and Output Driven Sales Personnel Performance Measures: Insights from an Experiment. International Journal of Case Studies in Business, IT, and Education (IJCSBE), 4(1), 23-37.

[47] Ganesha, H. R., Aithal, P. S. \& Kirubadevi, P. (2020). Decentralized Discounting Framework: Insights from an Experiment. International Journal of Applied Engineering and Management Letters (IJAEML), 4(1), 20-40.

[48] Ganesha, H. R., Aithal, P. S. \& Kirubadevi, P. (2020). Integrated Inventory Management Control Framework. International Journal of Management, Technology, and Social Sciences (IJMTS),5(1), 147-157.

[49] Ganesha, H. R., Aithal, P. S. \& Kirubadevi, P. (2020). Need-Based Sales Pitch: Insights from an Experiment. International Journal of Case Studies in Business, IT, and Education (IJCSBE),4(1), 79-87.

[50] Ganesha, H. R., \& Aithal, P. S. (2020). Sales Personnel Training - An Integrated Framework for Indian Brick-and-Mortar Retailers. International Journal of Case Studies in Business, IT, and Education (IJCSBE), 4(1), 172-187.

[51] Ganesha, H. R., Aithal, P. S. \& Kirubadevi, P. (2020). Integrated Marketing Mix Framework for Baby Care Retailing in India. International Journal of Applied Engineering and Management Letters (IJAEML),4(1), 191-218.

[52] Ganesha, H. R.,\& Aithal, P. S. (2020). Measuring True Potential of Lifestyle Brands in India: A Firm-Level Scale for Existing and Potential Investors (FL-LBSi). International Journal of Applied Engineering and Management Letters (IJAEML), 4(1), 279-302.

[53] Ganesha, H. R., \& Aithal, P. S. (2020). Measuring True Potential of Lifestyle Brands in India: A Consumer-Level Scale for Existing and Potential Investors (CCF-LS). International Journal of Case Studies in Business, IT, and Education (IJCSBE), 4(1), 207-222.

$* * * * * * * * * * *$ 